\title{
PENGARUH KOMPENSASI, LEVERAGE, UKURAN PERUSAHAAN , DAN DIVIDEN TERHADAP TURNOVER: STUDI EMPIRIS PADA PERUSAHAAN PERBANKAN DI INDONESIA
}

\author{
EVY RAHMAN UTAMI \\ ETIK KRESNAWATI \\ EKA DWIYANTI PUTJE \\ Universitas Muhammadiyah Yogyakarta, Jl. Brawijaya, Geblagan, Tamantirto, Kec. Kasihan, Bantul, Daerah \\ Istimewa Yogyakarta 55183, Indonesia \\ evyrahmanutami@yahoo.com
}

\begin{abstract}
This study aimed to show empirical evidence of the correlation between compensation, leverage, dividend and firm size with the CEO turnover of banking companies in Indonesia. This study used banking companies in 2009 - 2016. The total research samples were 41 companies. The data analysis used multiple regression. The result of the study indicated that compensation, leverage and firm size had no correlation with the CEO turnover of the banking companies. However, the dividend had positive and significance influence towards the CEO turnover of the directors. Compensation given to the board of directors were unable to align the interests of management and shareholders. Besides, the directors did not take leverage and total assets in the CEO turnover consideration. Nevertheless, they consider dividend distribution conducted by the company.
\end{abstract}

Keywords: Turnover, compensation, leverage, firm size, dividend

Abstrak: Penelitian ini bertujuan untuk menunjukkan bukti empiris tentang korelasi antara kompensasi, leverage, dividen dan ukuran perusahaan dengan perputaran CEO perusahaan perbankan di Indonesia. Penelitian ini menggunakan perusahaan perbankan pada tahun 2009-2016. Total sampel penelitian adalah 41 perusahaan. Analisis data menggunakan regresi berganda. Hasil penelitian menunjukkan bahwa kompensasi, leverage dan ukuran perusahaan tidak memiliki korelasi dengan perputaran CEO perusahaan perbankan. Namun, dividen memiliki pengaruh positif dan signifikan terhadap pergantian direksi. Kompensasi yang diberikan kepada dewan direksi tidak dapat menyelaraskan kepentingan manajemen dan pemegang saham. Selain itu, para direktur tidak mengambil leverage dan total aset dalam pertimbangan perputaran CEO. Namun demikian, mereka mempertimbangkan pembagian dividen yang dilakukan oleh perusahaan.

Kata kunci: $\quad$ Perputaran, kompensasi, leverage, ukuran perusahaan, dividen 


\section{PENDAHULUAN}

Pergantian dewan direksi di bank milik BUMN merupakan hal biasa yang dilakukan (Rossiana 2018). Misalnya, Suprajarto diangkat menjadi direktur utama PT Bank Rakyat Indonesia pada Maret 2017 dan sebelumnya pernah menjabat wakil direktur utama PT Bank Negara Indonesia. PT Bank MNC juga menyetujui pengangkatan Mahdan dan Hermawan sebagai direksi. Pergantian direksi untuk memperkuat jajaran manajemen dalam rangka upaya Bank MNC dalam menjaga dan memperkuat rentabilitas (Yudistira 2018). Selain itu, sistem manajemen perusahaan membutuhkan pembentukan tim inti yang kuat dan bertanggungajawab dalam menetapkan tujuan dan memiliki strategi yang baik dalam mencapainya (Lindrianasari \& Hartono 2012). Hal ini menjadi dasar dalam menentukan pola kerja perusahaan, arah, dan tingkat kinerja perusahaan yang ingin diraih. Perusahaan seharusnya memiliki tim manajemen yang kuat untuk mengatasi persaingan dalam dunia bisnis yang tidak terduga. Namun, motivasi turnover direksi pada perusahaan perbankan BUMN di Indonesia masih belum jelas. Supriyanto (2018) menjelaskan turnover direksi perbankan BUMN bukan karena lambatnya pertumbuhan kredit dan key performance indicator (KPI) melainkan lebih karena hubungan batin antara kementerian Badan Usaha Milik Negara (BUMN) dan direktur utamanya.

Di Indonesia, peraturan Otoritas Jasa Keuangan Nomor 3/POJK.04/2014 mengatur mengenai direksi dan dewan komisaris emiten atau perusahaan publik. Pasal 3 Nomor 3/POJK.04 Tahun 2014 menjelaskan bahwa anggota direksi diangkat dan diberhentikan oleh Rapat Umum Pemegang Saham (RUPS), anggota direksi diangkat untuk masa jabatan tertentu serta dapat diangkat kembali, dan satu periode masa jabatan paling lama lima tahun atau sampai dengan penutupan RUPS tahunan pada akhir satu periode masa jabatan. Turnover dalam penelitian ini didefinisikan sebagai perputaran posisi eksekutif dalam hal ini dewan komisaris dan dewan direksi (Smith, Wright, \& Huo, 2008). Dewan komisaris dan dewan direksi mempunyai peran penting dalam meningkatkan kemampuan perusahaan. Pergantian dewan komisaris dan dewan direksi ada yang direncanakan dan ada yang tidak direncanakan. Biasanya dorongan pribadi untuk berpindah karena dorongan yang kuat untuk berubah, sementara banyak CEO yang diberhentikan karena memiliki perilaku yang tidak bermoral.

Penelitian mengenai turnover, khususnya di Indonesia, belum banyak dilakukan. Penelitian turnover pernah dilakukan oleh Sarkar (2018), Loyeung \& Matolcsy (2015), Blackwell et al. (2007) dan (Lindrianasari \& Hartono 2012). Sarkar (2018) meneliti mengenai sejauh mana literatur kompensasi dan turnover serta membahas mengenai pergeseran fokus dan pentingnya pemberian kompensasi sebagai sarana untuk mempengaruhi turnover. Loyeung \& Matolcsy (2015) membangun wawasan mengenai peran CFO, kompensasi dan turnover. Blackwell et al. (2007) fokus pada CEO turnover dan kinerja perusahaan, sedangkan Lindrianasari \& Hartono (2012) menguji kegunaan informasi akuntansi dan pasar ketika mempertimbangkan masalah pergantian CEO di Indonesia. Selain itu, Juhdi, $\mathrm{Pa}$, Milah, \& Hansaram (2013) menghubungkan turnover dengan komitmen organisasi. Variasi penelitian mengenai turnover tidak hanya dilihat dari aspek keperilakuan tetapi perlu di teliti dalam perspektif internal perusahaan.

Beberapa variabel yang diduga mempengaruhi turnover dan diteliti dalam penelitian ini adalah kompensasi, leverage, ukuran perusahaan, dan dividen. Penelitian ini sangat penting karena bisa membuat kontribusi terhadap pengambilan keputusan dalam sistem manajemen perusahaan (Lindrianasari \& Hartono 2012). Penelitian mengenai kompensasi sudah banyak dilakukan, misalnya di India (Ghosh \& Aggarwal 2011; Raithatha \& 
Komera 2016), di Amerika (Grace 2004, Harris \& Bromiley 2007, Sun, Wei, \& Huang 2013), di Italia (Gigliotti 2013), di China (Conyon \& He 2012), di Korea (Kato, Kim, \& Lee 2007), di Australia (Walker 2010), di Jepang (Kato \& Kubo 2006), di Selandia Baru (Gunasekaragea \& Wilkinson 2002), di Malaysia (Haron \& Akhtaruddin 2013). Sedangkan penelitianpenelitian di Asia sangat terbatas karena keterbatasan data mengenai pengungkapan kompensasi (Kato et al. 2007). Di Indonesia penelitian kompensasi pernah dilakukan oleh (Fahreza 2014, Sugiri, Febrianto, \& Kresnawati 2014, Ulupui, Utama, \& Karnen 2014, Utami 2017). Literatur yang ada sebagian besar melihat hubungan kinerja dengan kompensasi dan masih sedikit yang menguji hubungan kompensasi dengan turnover.

Teori agensi menggambarkan interaksi dan biasanya dalam bentuk konflik antara pemilik dan manajemen, termasuk masalah pergantian CEO. Teori agensi yang dikemukakan oleh (Jensen \& Meckling 1976) antara pemilik dan manajer dalam suatu perusahaan terkait asimetri informasi. Hal ini semakin mendorong para pemilik untuk membentuk perjanjian atau kontrak dengan para manajer dimana para manajer akan mengambil tindakan yang menyebabkan peningkatan kesejahteraan pemilik. Kinerja keuangan pada umumnya sebagai patokan dalam mengukur keberhasilan seorang manajer dalam meningkatkan kesejahteraan pemilik, diyakini menjadi salah satu pertimbangan penting dalam pergantian CEO. Asumsi yang digunakan dalam teori keagenan bahwa kinerja akuntansi memiliki pengaruh terhadap pergantian CEO.

Penelitian ini menggunakan variabel dividen dalam model penelitian mengikuti penelitian yang pernah dilakukan oleh Yahya \& Ghazali (2016). Yahya \& Ghazali (2016) menginvestigasi dampak kinerja akuntansi dan kinerja pasar pada kompensasi yang dimoderasi oleh kebijakan dividen perusahaan. Namun, hasil penelitian Yahya \& Ghazali (2016) menunjukkan bahwa kebijakan dividen tidak mampu digunakan sebagai kontrol dan tidak mampu mencegah konflik pada perusahaan sektor keuangan di Pakistan. Selain kedua variabel tersebut, peneliti menduga bahwa kinerja perusahaan mampu mempengaruh turnover direksi, yaitu leverage dan ukuran perusahaan. Perusahaan dengan leverage tinggi kemungkinan akan menghadapi kesulitan yang lebih besar dalam mempertahankan perusahaan. Smith et al. (2008) dan Lindrianasari \& Hartono (2012) meneliti ukuran perusahaan dengan turnover. Ukuran perusahaan dapat memberikan skala ekonomis yang pada dasarnya mempengaruhi kinerja perusahaan (Mitra \& Adhikary 2017).

Penelitian ini bertujuan untuk menunjukkan bukti empiris hubungan antara kompensasi, leverage, ukuran perusahaan dan dividen dengan turnover. Disisi lain, penelitian ini bertujuan untuk membangun literatur mengenai fenomena turnover pada direktur perbankan di Indonesia. Penelitian ini penting untuk dilakukan karena masih sedikitnya literature dan adanya fenomena turnover direksi yang cukup tinggi pada perusahaan perbankan di Indonesia. Kedua, masalah kompensasi disorot oleh berbagai kalangan dalam kaitannya dengan kinerja yang dihasilkan dan kompensasi yang diberikan kepada manajemen (direksi) yang terus mengalami kenaikan setiap tahun. Selain itu, peneliti ini mengukur turnover berbeda dengan penelitian yang pernah dilakukan oleh Lindrianasari \& Hartono (2012).

Penelitian ini berkontribusi pada literatur dan mampu menjawab perdebatan yang dilakukan oleh berbagai pihak mengenai kompensasi. Selain itu, penelitian ini juga dapat digunakan dalam praktik terkait dengan regulasi kompensasi yang berlaku di perusahaan yang terdaftar di Bursa Efek. Di sisi lain, penelitian ini juga menyediakan pentingnya informasi untuk para penyusun standar dalam mendemonstrasikan kompensasi dan nilai perusahaan. 


\section{Teori Keagenan}

Teori keagenan merupakan pemisahan kepemilikan dan pengelolaan yang menciptakan konflik keagenan (Jensen \& Meckling, 1976). Konflik terjadi karena informasi yang tidak simetris, manajer memiliki informasi yang lebih banyak yang tidak dimiliki oleh pemegang saham. Salah satu tanggungjawab utama dari dewan komisaris memberikan insentif yang efisien untuk direksi untuk mengurangi masalah keagenan (Jensen \& Meckling, 1976). Konflik antara pemegang saham dan manajer dapat diatasi dengan menyelaraskan kepentingan manajer dan pemilik (Jensen \& Murphy 1990). Ada beberapa cara untuk menyelaraskan kepentingan antara manajer dengan pemilik, misalnya pemberian kompensasi kepada manajer dan pembagian dividen kepada pemilik. Nyberg, Fulmer, Gerhart, \& Carpenter (2010) menjelaskan keselarasan insentif melibatkan dua komponen yaitu keselarasan keuangan dan keselarasan preferensi \& tindakan. Keselarasan keuangan adalah imbalan ekonomi manajer berkaitan dengan pemilik melalui kepemilikan dan atau kompensasi.

Pemegang saham pada umumnya menginginkan return perusahaan yang tinggi tetapi manajer lebih berfokus pada kinerja jangka pendek karena manajer sangat tergantung pada perusahaan yang mereka kelola. Paket kompensasi dirancang untuk menarik kecanggihan manajemen, mendorong usaha manajerial, dan meminimalkan biaya keseluruhan. Kecanggihan manajemen sangat penting. Manajer yang memiliki kecanggihan lebih besar akan mengarah pada paket kompensasi yang lebih tinggi, misalnya insentif jangka pendek biasanya diberikan dalam bentuk bonus, sedangkan insentif dalam jangka panjang diberikan dalam wujud opsi saham. Posisi yang menguntungkan antara kedua belah pihak menimbulkan lingkungan kerja yang nyaman sehingga tingkat turnover direksi diharapkan semakin kecil.

\section{Pengembangan Hipotesis}

Teori keagenan menjelaskan penggunaan kompensasi sebagai mekanisme perilaku manajer dalam memaksimalkan kepentingan pemegang saham (Bebchuk \& Fried 2003). Penelitian menunjukkan bahwa pemberian kompensasi dapat mengurangi tingkat turnover (Juhdi et al. 2013). Penelitiannya dilakukan pada 457 karyawan yang bekerja di berbagai perusahaan di Malaysia. Pemberian kompensasi kepada manajer terbukti memotivasi para manajer untuk bekerja lebih baik. Sarkar (2018) meneliti secara komprehensif mengenai hubungan kompensasi dan turnover dan hasilnya menunjukkan bahwa pemberian kompensasi sebagai alat untuk mengikat karyawan sehingga dapat mengurangi intensitas untuk meninggalkan organisasi. Kompensasi merupakan faktor penghubung yang membagawa pekerja dan tujuan organisasi dapat tercapai dengan bersama-sama (Sarkar, 2018). Kompensasi yang diberikan kepada manajer dapat menahan direksi untuk tidak berpindah kerja atau mampu menciptakan komitmen pada direksi. Intensitas turnover yang rendah menyebabkan perusahaan memperoleh manfaat dan keuntungan karena perusahaan tidak mengeluarakan biaya untuk merekrut karyawan baru. Perusahaan akan mengalami kemunduran kualitas dan produktivitas seandainya ditinggalkan oleh para direksi yang profesional. Kompensasi sebagai instrumen untuk mengikat komitmen dewan direksi kepada perusahaan. Berdasarkan penjelasan diatas, peneliti mengajukan hipotesis sebagai berikut: $\mathrm{H}_{1}$ Kompensasi berpengaruh negatif terhadap turnover dewan direksi.

Lindrianasari \& Hartono (2012) meneliti menggunakan berbagai macam indikator keuangan dalam melihat pengaruh kinerja akuntansi dengan turnover. Perusahaan yang memiliki leverage yang tinggi menjadi perhatian khusus para direksi. Mereka bekerja memilih 
pada perusahaan yang sehat dan bertumbuh. Leverage yang terlalu tinggi di dalam suatu perusahaan akan menjadi beban tambahan bagi direksi. Oleh karena itu, direksi akan memilih perusahaan yang memiliki leverage yang rendah. Selain itu, posisi keuangan yang kurang baik misalnya leverage tinggi akan merusak nama baik atau citra dewan direksi dan dipertanyakan kemampuan dalam mengelola perusahaan. Berdasarkan penjelasan diatas, peneliti mengajukan hipotesis sebagai berikut:

$\mathrm{H}_{2}$ Leverage berpengaruh positif terhadap turnover dewan direksi.

Smith et al. (2008) meneliti hubungan ukuran perusahaan dengan turnover. Hasil penelitiannya menunjukkan bahwa total aset berpengaruh negatif terhadap turnover CEO. Selain itu penelitian Lindrianasari \& Hartono (2012) menunjukkan bahwa total aset dalam suatu perusahaan akan menjadi dasar pertimbangan CEO terkait keputusan untuk turnover. Total aset umumnya digunakan untuk mengukur pertumbuhan perusahaan. Ukuran perusahaan yang tinggi mendorong perusahaan untuk menciptakan skala ekonomi yang akan berdampak pada kinerja perusahaan (Mitra \& Adhikary 2017). Oleh karena itu, direksi yang bekerja pada perusahaan yang asetnya tinggi akan tetap bertahan di perusahaan tersebut. Perusahaan yang tumbuh asumsinya perusahaan akan semakin berkembang sehingga direksi memiliki prospek yang baik dan tidak perlu berpindah tempat kerja. Berdasarkan penjelasan diatas, peneliti mengajukan hipotesis sebagai berikut:

$\mathrm{H}_{3}$ Ukuran perusahaan berpengaruh negatif terhadap turnover dewan direksi.

Penelitian Yahya \& Ghazali (2016) menggunakan variabel dividen untuk melihat hubungan kompensasi dengan kinerja. Ada 2 pandangan dalam memaknai pembagian dividen. Pertama, pembagian dividen bagi direksi menjadi signal yang kurang baik karena perusahaan tidak dapat mengembangkan perusahaan lebih luas. Kedua, pembagian dividen menjadi signal yang baik bagi para investor karena investor menangkap bahwa keuangan perusahaan dalam kondisi yang baik jika perusahaan mampu membagikan dividen kepada para pemegang saham. Pemberian dividen diharapkan menambah loyalitas direksi untuk tidak berpindah kerja. Pembagian dividen akan mengurangi laba ditahan dan kas yang tersedia namun pendistribusian keuntungan kepada pemilik memang salah satu tujuan dari organisasi bisnis. Perusahaan membagi dividen kepada pemilik menandakan keuangan perusahaan sehat dan perusahaan memiliki prospek yang baik. Namun, pembagian dividen juga mendorong direktur untuk memilih meninggalkan perusahaan. Berdasarkan penjelasan diatas, peneliti mengajukan hipotesis sebagai berikut:

$\mathrm{H}_{4}$ Dividen berpengaruh positif dengan turnover dewan direksi.

\section{METODE PENELITIAN}

Penelitian ini menggunakan sampel perusahaan perbankan di Indonesia periode 2009-2016 yang terdaftar di Bursa Efek Indonesia (BEI). Penggunaan sampel hanya perusahaan perbankan karena di Indonesia hanya perusahaan perbankan yang mengungkapkan bonus dewan direksi. Pengambilan data dilakukan secara purposive sampling sebagai berikut:

a. Perusahaan perbankan yang menyajikan laporan tahunan dan laporan keuangan selama periode $2009-2016$.

b. Perusahaan mengungkapkan bonus dewan direksi.

c. Perusahaan melakukan turnover dewan direksi

d. Perusahaan memiliki data-data yang diperlukan untuk penelitian. 
Data yang digunakan diperoleh dari laporan tahunan perusahaan. Jumlah sampel perusahaan perbankan periode pengamatan 2009-2016 berjumlah 252 tetapi sampel yang memenuhi purposive sampling hanya 41 sampel. Perusahaan perbankan di Indonesia tidak secara konsisten mengungkapkan besaran gaji, tunjangan, dan bonus secara terpisah antara dewan komisaris dan dewan direksi. Tabel 1 adalah daftar sampel penelitian:

Tabel 1 Sampel Penelitian

\begin{tabular}{lllllllll}
\hline No & Tahun & Kode & No & Tahun & Kode & No & Tahun & Kode \\
\hline 1 & 2009 & BBKP & 15 & 2011 & BJBR & 29 & 2014 & BBNI \\
2 & 2009 & BBNI & 16 & 2011 & BMRI & 30 & 2014 & BBTN \\
3 & 2009 & BDMN & 17 & 2011 & SDRA & 31 & 2014 & BDMN \\
4 & 2009 & BMRI & 18 & 2012 & BJBR & 32 & 2014 & BJBR \\
5 & 2010 & BABP & 19 & 2012 & BMRI & 33 & 2014 & BMRI \\
6 & 2010 & BBKP & 20 & 2012 & SDRA & 34 & 2014 & BNGA \\
7 & 2010 & BBTN & 21 & 2013 & BBKP & 35 & 2014 & BNLI \\
8 & 2010 & BDMN & 22 & 2013 & BBNI & 36 & 2014 & BVIC \\
9 & 2010 & BMRI & 23 & 2013 & BBTN & 37 & 2015 & BBNI \\
10 & 2010 & BNBA & 24 & 2013 & BDMN & 38 & 2015 & BBTN \\
11 & 2010 & SDRA & 25 & 2013 & BJBR & 39 & 2015 & BDMN \\
12 & 2011 & BABP & 26 & 2013 & BMRI & 40 & 2015 & BJBR \\
13 & 2011 & BBNI & 27 & 2013 & SDRA & 41 & 2015 & BMRI \\
14 & 2011 & BBTN & 28 & 2014 & AGRO & & & \\
\hline
\end{tabular}

Turnover didefinisikan mengenai perpindahan dewan direksi diukur dengan menggunakan rumus jumlah direksi yang berpindah dibagi dengan total direksi. Peneliti mengidentifikasi secara manual dengan melihat laporan tahunan perusahaan dengan cara mengidentifikasi nama-nama CEO dan membandingkan dengan nama-nama tahun sebelumnya.

Kompensasi dalam bentuk kas yaitu gaji, tunjangan dan bonus dan dewan direksi (Cheng 2004). Peneliti menghitung kompensasi menggunakan delta jumlah total kompensasi dewan direksi. Data kompensasi dikumpulkan secara manual dari laporan keuangan perusahaan yang sudah diaudit. Leverage digunakan untuk mengukur pendanaan. Leverage diukur dengan logaritma total hutang dibagi total aset (Fahreza 2014). Disisi lain, ukuran perusahaan diukur dengan logaritma total aset (Mitra \& Adhikary 2017, Xiao, He, Lin,
\& Elkins 2013). Data untuk menghitung leverage, dividen dan ukuran perusahaan diambil dari laporan tahunan perusahaan.

Penelitian ini menggunakan analisis regresi berganda. Hipotesis 1 dan hipotesis 3 terdukung apabila nilai sig lebih kecil dari alpha $(0,05)$ dan koefisien regresi bernilai negatif, sedangkan hipotesis 2 dan hipotesis 4 terdukung apabila nilai sig lebih lebih kecil dari alpha $(0,05)$ dan koefisien regresi bernilai positif. Persamaan regresi hipotesis 1 sampai hipotesis 4 sebagai berikut:

Turnover $_{i, t+1}=a+\beta_{1}$ Komp $+\beta_{2} L V_{i, t}+\beta_{3} T A+$

$$
\beta_{4} D E V+e
$$

Keterangan Komp $\mathrm{i}_{\mathrm{i}, \mathrm{t}}$ Kompensasi i pada tahun $\mathrm{t}$, Turnover $_{i, t+1}$ Turnover direksi i pada tahun $t+1$, $L V_{i, t}$ Leverage perusahaan i pada tahun $t, T A, t$ Total Aset i pada tahun t, DEV,$t$ Dividen i pada tahun $t$, a Konstanta, e Error, $\beta_{1}-\beta_{4}$ Koefisien regresi. 


\section{HASIL PENELITIAN}

Hasil statistik deskriptif dan pengujian hipotesis dapat dilihat pada tabel berikut:

Tabel 2 Statistik Deskriptif

\begin{tabular}{lcccc}
\hline Variabel & Minimum & Maksimum & Rerata & Deviasi Standar \\
\hline TurnOver & 0,00 & 0,91 & 0,36 & 0,32 \\
Ln_Komp & 14,80 & 19,63 & 17,65 & 1,30 \\
Leverage & 0,81 & 0,94 & 0,88 & 0,04 \\
LnTotalAset & 21,70 & 27,54 & 25,14 & 1,65 \\
Dividen & 0,00 & 269,56 & 69,20 & 68,67 \\
\hline
\end{tabular}

Tabel 3 Hasil Pengujian Hipotesis

\begin{tabular}{lccc}
\hline \multicolumn{1}{c}{ Variabel } & Koefisien & $\mathbf{t}$ & Sig \\
\hline Konstanta & 1,105 & 0,627 & 0,535 \\
LnKompensasi & $-0,055$ & $-0,431$ & 0,669 \\
Leverage & 1,015 & 0,577 & 0,567 \\
LnTotalAset & $-0,035$ & $-0,363$ & 0,718 \\
Dividen & 0,003 & 2,134 & $0,040^{\star}$ \\
\hline
\end{tabular}

Pemberian kompensasi kepada dewan direksi pada perusahaan perbankan di Indonesia tidak berpengaruh pada turnover. Literature sebelumnya Blackwell et al. (2007); Loyeung \& Matolcsy (2015) meneliti mengenai kompensasi dan CEO turnover. Ada perbedaan sistem Top Management Team antara di Indonesia dan negara lain yang menjadi sampel dalam literatur. Sampel pada literatur sebelumnya menganut sistem one-tier, sedangkan penelitian ini dilakukan di Indonesia yang menganut sistem two-tier, yaitu memisahkan antara dewan komisaris dan dewan direksi. Penelitian ini hanya menganalisis kompensasi dan turnover khusus dewan direksi. Sarkar (2018) menjelaskan kompensasi merupakan faktor penghubung antara pekerja dan tujuan organisasi serta kompensasi adalah masalah penting yang dihadapi oleh perusahaan. Kompensasi dalam dimensi strategis bukan merupakan faktor biaya tetapi faktor yang menambahkan nilai ekonomi bagi organisasi dalam hal merekrut bakat terbaik untuk mendorong organisasi mencapai keunggulan kompetitif sehingga kompensasi mempromosikan komitmen untuk direksi sehingga mengurangi niat untuk meninggalkan organisasi (Sarkar 2018). Guthrie dalam Sarkar (2018) menemukan bahwa sistem kompensasi menyebabkan rasa komitmen pada karyawan dan menghasilkan retensi tenaga kerja. Selain itu, Moncarz et al. (2009) berpendapat bahwa kompensasi memainkan peran penting dalam retensi dan kinerja. Disisi lain, McElroy (2001) menyarankan bahwa kompensasi mengikat pada kinerja organisasi yang meningkatkan komitmen dan mengurangi perilaku negatif terkait ketidakhadiran dan meninggalkan organisasi.

Whitener (2001) menjelaskan sistem kompensasi yang efektif yaitu yang adil dari sisi internal dan kompetitif dari perspektif ekstenal akan menunjukkan nilai-nilai organisasi yang berkontribusi pada karyawan melalui komitmen dan kepercayaan terhadap organisasi. Sistem kompensasi berpengaruh positif terhadap banyak aspek yaitu, komitmen, kepuasan kerja, dan mengurangi keinginan meninggalkan organisasi (Sarkar 2018). Kompensasi adalah 
cara untuk menyampaikan bahwa karyawan itu penting di dalam organisasi.

Kompensasi sebagai alat untuk menyelaraskan kepentingan antara manajer dan pemilik dalam penelitian ini tidak terbukti. Penelitian ini tidak sejalan dengan teori keagenan dan penelitian sebelumnya yang dilakukan oleh Juhdi et al. (2013). Namun, penelitian Juhdi et al. (2013) menggunakan sampel dari berbagai macam sektor pada perusahaan di Malaysia. Hal ini menjadi menarik perhatian karena pemberian kompensasi oleh perusahaan perbankan di Indonesia umunya paling tinggi dibandingkan dengan sektor yang lain. Hampir setiap tahun kompensasi yang diberikan kepada CEO perusahaan perbankan mengalami peningkatan. Peneliti menduga CEO turnover tidak hanya dimotivasi oleh faktor finansial yang mereka terima tetapi fenomena turnover yang ada di Indonesia bukan bersikap sukarela atau keinginan sendiri untuk berpindah. Umumnya, turnover yang ada karena sikap yang diberikan oleh perusahaan kepada direksi.

$\mathrm{H}_{2}$ terdukung jika nilai sig lebih kecil dari alpha $(0,05)$ dan koefisien regresi leverage $(\beta 2)$ bernilai positif. Tabel 3 menunjukkan bahwa leverage tidak berpengaruh secara signifikan karena nilai sig 0,567 lebih besar dari alpha 0,05 . Hipotesis 2 tidak terdukung. Posisi leverage perusahaan perbankan di Indonesia tidak menjadi faktor penentu direktur melakukan turnover. Turnover terjadi karena sikap yang diberikan perusahaan kepada direksi. Perusahaan yang tidak mempermasalahkan posisi keuangan khusus leverage dalam periode tertentu maka tidak akan terjadi pergantian direksi. Permasalahan leverage merupakan masalah yang pasti dihadapi oleh suatu perusahaan. Secara teori, seandainya leverage perusahaan tinggi maka tingkat turnover juga semakin tinggi karena direksi mengalami risiko terhadap hutang yang ditanggung oleh perusahaan. Leverage yang tinggi bisa mengancam posisi keuangan perusahaan dan merusak reputasi direksi. Stakeholder mengasumsikan bahwa leverage yang terlalu tinggi mengindikasikan ketidakprofesionalan direksi. Namun, direksi perusahaan perbankan di Indonesia tidak menempatkan posisi leverage untuk menjadi bahan pertimbangan dalam turnover. Penelitian ini tidak sejalan dengan penelitian Lindrianasari \& Hartono (2012) dan teori keagenan. Peraturan OJK pasal 4 Nomor 3/POJK.04 Tahun 2014 menjadi perhatian penting bagi direksi bahwa dalam waktu 5 tahun sebelum pengangkatan dan selama menjabat dewan direksi dan dewan komisaris tidak pernah pailit atau tidak pernah menjadi direksi atau komisaris yang dinyatakan bersalah sehingga menyebabkan pailit. Pernyataan tersebut mengandung makna bahwa karakteristik perusahaan seharusnya menjadi alternatif dalam pemilihan perusahan sebagai tempat meniti karir direksi. Menariknya, dewan direksi pada perusahaan perbankan tidak mengkhawatirkan apabila perusahaan dalam kondisi leverage yang tinggi. Peneliti menduga ada faktor kekerabatan atau pertemanan yang menjadi pertimbangan direksi.

$\mathrm{H}_{3}$ terdukung jikai nilai sig lebih kecil dari alpha $(0,05)$ dan koefisien regresi total aset (B3) bernilai negatif. Tabel 3 menunjukkan bahwa total aset tidak berpengaruh secara signifikan karena nilai sig 0,718 lebih besar dari alpha 0,05. Hipotesis 3 tidak terdukung. Seharusnya semakin besar total aset yang dimiliki perusahaan maka intensitas turnover seharusnya menurun. CEO turnover perusahaan sektor perbankan di Indonesia tidak menempatkan porsi yang penting pada aspek jumlah aset perusahaan. Penelitian ini tidak sejalan dengan penelitian Smith et al. (2008) dan penelitian Lindrianasari \& Hartono (2012). Penelitian Lindrianasari \& Hartono (2012) menggunakan seluruh perusahaan di Indonesia namun penelitian Lindrianasari \& Hartono (2012) pengukuran turnover menggunakan dummy variabel yaitu 1 jika turnover dan 0 jika tidak turnover. Lindrianasari \& Hartono (2012) menunjukkan bahwa informasi akuntansi (total 
aset) berkontribusi dalam pengambilan turnover pada perusahaan di Indonesia. Peneliti menduga bahwa dewan direksi tidak terpengaruh dengan total aset perusahaan karena dewan direksi mempertimbangkan faktor lain. Pertama, dewan direksi mungkin dapat menikmati dan merasa nyaman dengan fasilitas non finansial yang diberikan oleh perusahaan. Selain itu, peneliti menduga bahwa dewan direksi memiliki pandangan yang sama dengan budaya organisasi di tempat mereka bekerja. Dewan direksi kemungkinan memiliki motivasi yang tinggi untuk memperbaiki perusahaan atau loyalitas tinggi dibandingkan hanya memikirkan kepentingan individu.

$\mathrm{H}_{4}$ terdukung jikai nilai sig lebih kecil dari alpha $(0,05)$ dan koefisien regresi dividen ( $\beta 4$ ) bernilai positif. Tabel 3 menunjukkan bahwa dividen berpengaruh secara signifikan dengan turnover karena nilai sig 0,040 lebih kecil dari alpha 0,05 dan koefisien regresi bernilai positif. Hipotesis 4 terdukung. Pemberian dividen kepada pemegang saham berpengaruh positif dengan turnover direksi. DeAngelo, DeAngleo, \& Stulz (2006) menjelaskan perusahaan membayar dividen untuk mengurangi biaya agensi dan digunakan untuk mengontrol ketika ketentuan tata kelola tidak menguntungkan pemegang saham. Menurut hipotesis arus kas bebas, perusahaan membayar dividen untuk mengurangi arus kas bebas sehingga para direksi tidak akan dapat menyalahgunakan melalui investasi berlebihan atau investasi dalam proyek NPV negatif (Sarkar 2018). Disisi lain, pemegang lebih suka bahwa manajer mendistribusikan uang dalam hal dividen jika tidak ada proyek NPV positif untuk diinvestasikan. Manajer berkualitas tinggi mendapatkan akses ke beberapa proyek NPV positif tetapi manajer yang kurang efisien membagikan dividen karena tidak dapat menemukan peluang investasi yang lebih baik. Pembagian dividen mengurangi biaya agensi dan memaksa manajer untuk mengungkapkan informasi baru untuk mengamankan dana yang diperlukan (Sarkar 2018). Hasil penelitian ini tidak sejalan denga teori keagenan karena tidak mampu memitigasi konflik keagenan antara pemegang saham dan direksi. Ketika pembagian dividen dilakukan maka keinginan pindah direksi juga semakin besar. Perspektif lain menjelaskan bahwa direksi yang memberikan dividen akan semakin percaya diri dengan prospek perusahaan di masa yang akan datang. Pemberian dividen merupakan signal yang baik bagi invenstor dan salah satu tujuan bisnis juga tercapai. Penelitian ini sejalan dengan Yahya \& Ghazali (2016) yang menunjukkan bahwa dividen tidak bisa memitigasi konflik keagenan dan tidak efisien.

\section{PENUTUP}

Hipotesis mengenai kompensasi, leverage dan ukuran perusahaan tidak berpengaruh terhadap turnover direksi perbankan di Indonesia. Disisi lain, dividen berpengaruh positif dan signifikan terhadap turnover. Penelitian ini menduga ada keunikan tersendiri pada perusahaan perbankan di Indonesia dan turnover direksi dipengaruhi oleh faktor luar dan tidak dipengaruhi oleh informasi akuntansi. Peneliti menduga ada kecocokan antara direksi dengan budaya organisasi dan loyatitas yang tinggi terhadap perusahaan, faktor budaya dan politik (misal BUMN: dipengaruhi oleh penguasa).

Penelitian ini memiliki keterbatasan dalam pengukuran turnover direksi. Peneliti seharusnya menggunakan data panel dalam penelitian ini sehingga diperoleh pembahasan yang komprehensif mengenai turnover dewan direksi pada perusahaan perbankan di Indonesia. Selain itu, kompensasi seharusnya mengeluarkan kompensasi dalam bentuk gaji pokok (tetap). Bonus yang diberikan kepada direksi bersifat variabel sehingga lebih tepat dalam penelitian ini. Namun demikian, ketidaktersediaan data tersebut membuat peneliti menggunakan kompensasi total dengan 
asumsi bahwa perubahan yang terjadi dalam kompensasi berasal dari kompensasi (bonus).

\section{Ucapan Terima Kasih}

Penelitian ini didanai oleh LP3M UMY dalam skema hibah penelitian kemitraan.

\section{REFERENSI:}

Bebchuk, L. A., \& Fried, J. M. 2003. Executive compensation as an agency problem. The Journal of Economic Perspectives, 17, 71-92.

Blackwell, D. W., Dudney, $\mathbb{E}$. D. M., \& Farrell, $\mathbb{E}$. K. A. 2007. Changes in CEO compensation structure and the impact on firm performance following CEO turnover. Review of Quantitative Finance and Accounting, 29(3), 315-338. https://doi.org/10.1007/s11156-007-0034-y

Cheng, S. 2004. R\&D Expenditures and CEO Compensation. The Accounting Review, 79(2), 305-328.

Conyon, M. J., \& He, L. 2012. CEO Compensation and Corporate Governance in China. Corporate Governance: An International Review, 20(6), 575-592. https://doi.org/10.1111/j.1467-8683.2012.00935.x

DeAngelo, Harry, Linda DeAngelo and Rene Stulz. 2006. Dividend policy and the earned/contributed capital mix: a test of the life-cycle theory. Journal of Financial Economics 81(2), 227-254.

Fahreza. 2014. Pengaruh kompensasi manajemen dan reputasi auditor terhadap manajemen pajak di perusahaan perbankan yang terdaftar di bursa efek indonesia. Simposium Nasional Akuntansi XVII Lombok.

Ghosh, A., \& Aggarwal, R. 2011. Directors remuneration various issues relating to firm performance. Paradigm XV, 93-102.

Gigliotti, M. 2013. The compensation of top managers and the performance of Italian firms. The International Journal of Human Resource Management, 24(4), 889-903. https://doi.org/10.1080/09585192.2012.702317

Grace, E. 2004. Contracting Incentives and Compensation for Property-Liability Insurer Executive. The Journal of Risk and Insurance, 71(2), 285-307.

Gunasekaragea, A., \& Wilkinson, M. 2002. CEO Compensation and Firm Performance: A New Zealand Investigation. International Journal of Business Studies, 10, 45-60.

Haron, H., \& Akhtaruddin, M. 2013. Determinants of Directors ' Remuneration in Malaysian Public Listed Companies. Indian Journal of Corporate Governanace, 6(2), 17-42.

Harris, J., \& Bromiley, P. 2007. Incentives to Cheat: The Influence of Executive Compensation and Firm Performance on Financial Misrepresentation. Organization Science, 18(3), 350-367. https://doi.org/10.1287/orsc.1060.0241

Jensen, M. C., \& Meckling, W. H. 1976. Theory of the Firm : Managerial Behavior , Agency Costs and Ownership Structure Theory of the Firm: Managerial Behavior, Agency Costs and Ownership Structure. Journal of Financial Economics, 3, 305-360.

Jensen, M. C., \& Murphy, K. J. 1990. Performance Pay and Top-Management Incentives. Journal of Political Economy, 98(2), 225-264.

Juhdi, N., Pa, F., Milah, R., \& Hansaram, K. 2013. HR Practices and Turnover Intention : The Mediating Roles of Organizational Commitment and Organizational Engagement in a Selected Region in Malaysia. The International Journal of Human Resource Management, 24(15), 3002-3019.

Kato, T., \& Kubo, K. (2006). CEO compensation and firm performance in Japan: Evidence from new panel data on individual CEO pay. Journal of the Japanese and International Economies, 20(1), 1-19. https://doi.org/10.1016/j.jjie.2004.05.003

Kato, T., Kim, W., \& Lee, J. H. (2007). Executive Compensation, Firm Performance, and Chaebols in Korea: Evidence from New Panel Data. Pacific-Basin Finance Journal, 15(1), 36-55. https://doi.org/10.1016/j.pacfin.2006.03.004

Lindrianasari, \& Hartono, J. 2012. Antecedent and Consequence Factors of CEO Turnover in Indonesia. Maanagement Research Review, 35(3/4), 206-224. https://doi.org/10.1108/01409171211210127 
Loyeung, A., \& Matolcsy, Z. 2015. CFO 's accounting talent, compensation and turnover. Accounting and Finance, $55,1105-1134$.

McElroy, J. C. 2001. Managing Workplace Commitment by Putting People First. Human Resource Management Review. https://doi.org/10.1016/S1053-4822(00)00054-1

Mitra, R. K., \& Adhikary, B. K. 2017. Determinants of Financial Performance: Empirical Evidence from the Textile Sector in Bangladesh. Journal of Accounting and Finance. Retrieved from http://eds.a.ebscohost.com/ehost/detail/detail?vid=0\&sid=11d40ed8-3de5-4ffe-93eccc60a0ab7bce\%40sessionmgr4006\&bdata=JnNpdGU9ZWhvc3QtbGI2ZQ\%3D\%3D\#AN=128937315\&db= bth

Moncarz, E., Zhao, J., \& Kay, C. 2009. An Exploratory Study of US Lodging Properties Organizational Practices on Employee Turnover and Retention. International Journal of Contemporary Hospitality Management, 21(4), 437-458.

Nyberg, A. J., Fulmer, I. S., Gerhart, B., \& Carpenter, M. A. 2010. Agency Theory Revisited: CEO Return and Shareholder Interest Alignment. Academy of Management Journal, 53(5), 1029-1049.

Raithatha, M., \& Komera, S. 2016. Executive compensation and firm performance: Evidence from Indian firms. IIMB Management Review, 28(3), 160-169. https://doi.org/10.1016/j.iimb.2016.07.002

Rossiana, G. 2018. Bongkar Pasang Jajaran Direksi Bank_Rossiana_2018. CNBC Indonesia. Retrieved from https://www.cnbcindonesia.com/market/20180322080521-17-8101/bongkar-pasang-jajaran-direksi-bankbumn

Sarkar, J. 2018. Linking Compensation and Turnover: Retrospection and Future Directions. The IUP Journal of Organizational Behavior, 17, 43-76. Retrieved from http://www.iupindia.in/405/ijob.asp

Smith, F., Wright, A., \& Huo, P. 2008. Scapegoating Only Works If the Herd Is Big: Downsizing, Management Turnover, and Company Turnaround. International Journal of Business Strategy, 8(3), 72-84.

Sugiri, S., Febrianto, R., \& Kresnawati, E. (2014). Perilaku Sticky Cost pada Kompensasi Eksekutif : Studi tentang Hubungan antara Kompensasi Eksekutif dan Pendapatan Bank di Empat Negara Asia Tenggara. Simposium Nasional Akuntansi XVII Lombok.

Sun, F., Wei, X., \& Huang, X. (2013). CEO compensation and firm performance: Evidence from the US property and liability insurance industry. Review of Accounting and Finance, 12(3), 252-267. https://doi.org/10.1108/RAF-Jan-2012-0006

Supriyanto, E. 2018. Rotasi Direksi Bank BUMN dan Keberanian Mengucurkan Kredit. Infobanknews. Retrieved from http://infobanknews.com/rotasi-direksi-bank-bumn-dan-keberanian-mengucurkan-kredit/

Ulupui, I. G. K. A., Utama, S., \& Karnen, K. A. 2014. Pengaruh kepemilikan keluarga, kedekatan direksi \& komisaris dengan pemilik pengendali terhadap kompensasi direksi \& komisaris perusahaan di pasar modal indonesia. Simposium Nasional Akuntansi XVII Lombok.

Utami, E. . 2017. Kinerja dan Kompensasi Masa Depan di Bank Syariah dan Konvensional. Jurnal Akuntansi Dan Keuangan Islam, 5(April), 83-96. Retrieved from http://jurnal.sebi.ac.id/index.php/jaki/issue/view/15

Walker, J. 2010. The Use of Performance-based Remuneration: High versus Low-growth Firms. Australian Accounting Review, 20(3), 256-264. https://doi.org/10.1111/j.1835-2561.2010.00098.x

Whitener, E. M. 2001. Do "HighCcommitment" Human Resource Practices Affect Employee Commitment? Journal of Management, 27(5), 515-535. https://doi.org/10.1177/014920630102700502

Xiao, Z., He, R., Lin, Z., \& Elkins, H. 2013. CEO compensation in China Accounting Performance, Corporate Governance, and the gender gap. Nankai Business Review International, 4(4), 309-328. https://doi.org/10.1108/NBRI-09-2013-0032

Yahya, F., \& Ghazali, Z. 2016. The Moderating Role of Dividend Policy in Aligning the Accounting and Market based performance Measures with CEO Compensation. International Journal of Management, Accounting and Economics, 3(6), 354-366.

Yudistira, G. 2018. RUPSLB Mahdan dan Hermawan masuk menjadi direksi Bank MNC. Kontan. 
